\title{
РОЛЬ РОЗРАХУНКОВО-ГРАФІЧНИХ ЗАВДАНЬ ПРИ ВИКЛАДАННІ РОЗДІЛУ “ФАЗОВІ РІВНОВАГИ” У КУРСІ ФІЗИЧНОЇ ТА КОЛОЇДНОЇ XIMIÏ
}

\author{
Л. Д. Грицан
}

Національний фармацевтичний університет

\section{THE ROLE OF CALCULATION-GRAPHICAL TASKS IN THE PROCESS OF TEACHING "PHASE EQUILIBRIA" SECTION IN THE COURSE OF PHYSICAL AND COLLOID CHEMISTRY}

L. D. Grytsan

\author{
National University of Pharmacy
}

\begin{abstract}
У статті розглянуто методичне значення розрахунково-графічних завдань для успішного викладання одного 3 найскладніших розділів модуля “Фізична хімія” студентам фармацевтичних спеціальностей.
\end{abstract}

The paper considers methodological significance of calculation-graphical tasks for successful teaching of one of the most difficult sections of the module "Physical chemistry" to students of pharmaceutical specialties.

Вступ. Відповідно до вимог Болонської конвенції у Національному фармацевтичному університеті була впроваджена кредитно-модульна система організації навчального процесу [1]. Це зумовило, зокрема, необхідність суттєвого перегляду методичних підходів до викладання фізичної та колоїдної хімії як фундаментальної дисципліни, в тому числі, поєднання різних форм навчання та контролю якості засвоєння матеріалу. Поряд із активним впровадженням інноваційних форм навчання [2], при підготовці майбутніх фахівців фармацевтичної галузі чільне місце мають посідати перевірені часом традиційні класичні методики викладання. Особливо це стосується складних для розуміння студентами питань розділу “Фазові рівноваги”, який входить до модуля “Фізична хімія” [3-5].

Основна частина. Багаторічний досвід викладання курсу фізичної та колоїдної хімії дозволяє стверджувати, що для кращого засвоєння теоретичного матеріалу розділу “Фазові рівноваги” викладач у першу чергу має навчити студентів характеризувати стан багатофазних одно- та двокомпонентних (бінарних) термодинамічних систем як функцію факторів рівноваги із використанням фазових діаграм (діаграм стану). Тому викладання розділу доцільно розпочинати з роз'яснення основного закону фазових рівноваг (правила фаз Дж. Гіббса), а також двох принципів

(ㄱ Л. Д. Грицан (відповідності та безперервності) М. С. Курнакова [6], які лежать в основі побудови та аналізу фазових діаграм, а також розрахунків за їх допомогою.

В однокомпонентних системах фази складаються з однієї речовини у різних агрегатних станах. Якщо речовина може утворювати різні кристалічні модифікації, то кожна $з$ них є окремою фазою. Наприклад, вода утворює шість різних модифікацій льоду, сірка кристалізується у ромбічній та моноклінній формах тощо. Для таких систем стан рівноваги визначається тиском $p$, температурою $T$ та об'ємом $V$. Тому діаграма стану є тривимірною, але для більшої зручності найчастіше розглядають іï проекцію на площину $p-T$. Згідно з правилом фаз Гіббса число ступенів свободи дорівнює $\mathrm{C}=3-\Phi$, де $\Phi-$ кількість фаз, за умови, що число зовнішніх факторів $n=2.3$ наведеного рівняння випливає, що в стані рівноваги знаходиться не більше трьох фаз, тобто можуть існувати одно-, дво- та трифазні однокомпонентні системи. Вид та розташування всіх кривих на діаграмах стану визначається за диференціальним рівнянням Клапейрона-Клаузіуса

$$
\frac{d p}{d T}=\frac{\Delta H_{\phi . n .}}{T\left(V_{2}-V_{1}\right)},
$$

де $\Delta H_{\phi, n}$ і $T$ - відповідно теплота та температура фазового переходу, $V_{1}$ та $V_{2}$ - молярні об'єми речовини у двох фазах. 
Для двокомпонентних систем фазові діаграми $є$ багатовимірними, тому, зазвичай, розглядають їх проекції на площину “фізична властивість - фактор рівноваги (склад)", що дозволяє визначити наявність та характер взаємодії між компонентами системи, області існування й склад рівноважних фаз без їх розділення на складові частини. У цьому полягає сутність фізико-хімічного аналізу, який, за визначенням М. С. Курнакова, являє собою геометричний метод дослідження хімічних перетворень. Ідея такого методу належить Д. І. Менделєєву. Подальший розвиток фізико-хімічного аналізу пов'язаний 3 роботами М. С. Курнакова та його учнів, а також Я. Вант-Гоффа, Г. Таммана, А. Ле Шательє, Д. П. Коновалова, В. Ф. Алєксєєва, Ю. Я. Фіалкова, В. М. Валяшка та інших вчених [6-19].

Для побудови фазової діаграми бінарної системи доцільно вивчати такі фізичні властивості, які $є$ чутливими до зміни іiї складу, наприклад, температуру плавлення, теплоємність, електричну провідність, показник заломлення, густину, в'язкість, поверхневий натяг та ін. У більшості випадків аналітичний вигляд функції, яка описує залежність певної фізичної властивості від складу системи, $є$ невідомим. Тому для вивчення цієї залежності діаграму стану будують за експериментальними даними. Сучасні обчислювальні методи дозволяють здобути додаткову інформацію з фазової діаграми. Наприклад, можна визначити ступінь дисоціації хімічної сполуки у розплаві на підставі аналізу кривини лінії ліквідуса. Залучення різних теорій твердого тіла, моделей рідини та ін., поряд з узагальненням експериментальних даних, дозволяє побудувати фазову діаграму (або ії елементи) розрахунковим шляхом.

Для фармацевтичної науки та технології найбільшого значення набули фазові діаграми бінарних систем, для побудови яких у якості фізичної властивості вимірюють температури плавлення (кристалізації), кипіння (конденсації), освітлення (помутніння). Аналіз фазових діаграм, які описують процеси плавлення (кристалізації), кипіння (конденсації) та взаємної розчинності двох рідин, сприяє оптимізації технологічних операцій хіміко-фармацевтичного, парфумерно-косметичного та біотехнологічного виробництв. Використання методу фізико-хімічного аналізу дозволяє збільшити вихід продуктів, зменшити енергозатрати та витрати вихідних і допоміжних речовин. Фазові діаграми застосовуються також у фармацевтичному аналізі для ідентифікації та визначення ступеня чистоти лікарських та допоміжних речовин [20, 21].
Розглянемо більш детально значення певних діаграм.

За діаграмами плавкості бінарних систем визначають склад сумішей (термічний аналіз), зокрема евтектичних, 3 метою прийняття рішення щодо сумісності діючих та допоміжних речовин при розробці технології виготовлення лікарських препаратів у вигляді порошків, супозиторіїв тощо [22]. Наприклад, камфора утворює 3 деякими лікарськими речовинами (антипірином, фенілсаліцилатом, ментолом) евтектичні суміші, які плавляться при кімнатній температурі, що призводить до погіршення якості лікарської форми або робить її виготовлення неможливим. Але в деяких випадках використовують саме евтектичні суміші лікарських речовин, наприклад, при виготовленні рідких лікарських форм для стоматології. Побудову діаграм плавкості застосовують також для вибору найбільш доцільного шляху виділення із сумішей та очищення лікарських речовин.

Діаграми кипіння бінарних сумішей рідин, що необмежено змішуються, складають теоретичну основу фракційної перегонки, яка застосовується як у фармацевтичному аналізі, так і в технології виробництва та очищення лікарських речовин, а також при розробці нових лікарських форм і препаратів.

Фазові діаграми бінарних систем обмежено розчинних рідин, побудовані в координатах “температура освітлення (помутніння) - склад" при $p=$ const, застосовують серед іншого у фармацевтичній практиці для визначення складу рідких лікарських форм, які не повинні розшаровуватися при зберіганні.

Розрахунково-графічні завдання пропонують студентам для закріплення вивченого теоретичного матеріалу. Їх можна виконувати як під керівництвом викладача, так і у вигляді аудиторної або позааудиторної самостійної роботи. За змістом вони представляють задачі, що включають побудову за експериментальними даними та аналіз фазових діаграм, а також розрахунки на їх основі.

Нижче наведені кілька прикладів подібних завдань $[14,23]$.

Приклад 1. Побудуйте діаграму плавкості для системи камфора - бензойна кислота за такими даними:

\begin{tabular}{|l|c|c|c|c|c|c|}
\hline $\begin{array}{l}\text { Масова частка } \\
\text { камфори, \% }\end{array}$ & 0 & 10 & 30 & 60 & 80 & 100 \\
\hline $\begin{array}{l}t \text { початку } \\
\text { кристалізації, }{ }^{\circ} \mathrm{C}\end{array}$ & 121 & 114 & 97 & 60 & 115 & 178 \\
\hline $\begin{array}{l}t \text { кінця } \\
\text { кристалізації, }{ }^{\circ} \mathrm{C}\end{array}$ & 121 & 56,5 & 56,5 & 56,5 & 57 & 178 \\
\hline
\end{tabular}


Студентам можна запропонувати виконати наступні завдання із використанням побудованої діаграми:

- визначити тип діаграми та проаналізувати ії із використанням правила фаз Гіббса;

- вказати склад та назву суміші, яка має найнижчу температуру плавлення (кристалізації);

- побудувати криву охолодження суміші, яка містить 40 \% камфори, від 100 до $70{ }^{\circ} \mathrm{C}$;

- визначити склад та масу рівноважних фаз, які утворились при охолодженні від 100 до 70 C вказаної у попередньому завданні суміші.

Приклад 2. При виробництві барбітурових препаратів як відходи утворюються суміші, що містять диметилформамід і етанол. 3 метою вибору оптимальних умов проведення регенерації вказаних компонентів були визначені склади рідини й парипри різних температурах і нормальному атмосферному тиску, які наведені в таблиці.

\begin{tabular}{|c|c|c|}
\hline \multirow{2}{*}{$t,{ }^{\circ} \mathrm{C}$} & мольні частки $\mathrm{C}_{2} \mathrm{H}_{5} \mathrm{OH}$ при рівновазі \\
\cline { 2 - 3 } & рідка фаза & пара \\
\hline 153,0 & 0 & 0 \\
\hline 138,5 & 0,15 & 0,54 \\
\hline 134,0 & 0,20 & 0,66 \\
\hline 126,5 & 0,30 & 0,79 \\
\hline 119,0 & 0,40 & 0,87 \\
\hline 115,5 & 0,45 & 0,90 \\
\hline 108,5 & 0,55 & 0,94 \\
\hline 99,0 & 0,70 & 0,97 \\
\hline 94,0 & 0,80 & 0,98 \\
\hline 89,0 & 0,85 & 0,99 \\
\hline 85,5 & 0,90 & 0,99 \\
\hline 81,5 & 0,95 & 0,99 \\
\hline 78,5 & 1,00 & 1,00 \\
\hline
\end{tabular}

В якості навчального завдання студентам пропонується за наведеними табличними даними побудувати діаграму кипіння системи диметилформамід етанол. Додатковими завданнями можуть бути такі:

- визначити температуру кипіння суміші, яка містить 5 моль диметилформаміду і 5 моль етанолу;

- визначити температуру, при якій закінчиться перегонка вказаної у попередньому завданні суміші, та склад останньої краплі рідкої фази.

\section{Списоклітератури}

1. Кредитно-модульна система організації навчання у контексті Болонського процесу в Національному фарма-
Приклад 3. Взаємна розчинність фенолу і води виражається такими даними $\left(w_{1}\right.$ i $w_{2}$ - масові частки фенолу в насичених рідких фазах, збагачених відповідно водою та фенолом):

\begin{tabular}{|c|c|c|}
\hline$t,{ }^{\circ} \mathrm{C}$ & $w_{l}, \%$ & $w_{2}, \%$ \\
\hline 20 & 8,40 & 72,24 \\
\hline 25 & 8,71 & 71,38 \\
\hline 30 & 8,92 & 69,95 \\
\hline 40 & 9,78 & 66,81 \\
\hline 45 & 10,62 & 65,02 \\
\hline 50 & 12,08 & 62,83 \\
\hline 55 & 13,88 & 60,18 \\
\hline 60 & 17,10 & 56,10 \\
\hline 65 & 22,26 & 49,34 \\
\hline 68,8 & 35,90 & 35,90 \\
\hline
\end{tabular}

Після побудови діаграми взаємної розчинності бінарної системи фенол - вода студентам доцільно запропонувати виконати наступні завдання:

- провести аналіз діаграми стану за допомогою правила фаз Гібсса;

- визначити критичну температуру розчинності;

- визначити склад системи, який відповідає критичній температурі розчинності;

- визначити максимально можливий вміст фенолу у водному розчині при $20^{\circ} \mathrm{C}$, який би відповідав гомогенній системі.

У спрощеному варіанті розрахунково-графічні завдання можуть містити фазові діаграми в готовому вигляді. В такому разі студентам рекомендується провести їх аналіз із використанням правила фаз Гіббса та розрахунки за допомогою правила важеля.

Висновки: 1. Виконання профілізованих ситуаційних розрахунково-графічних завдань дозволяє студентам краще зрозуміти значення курсу фізичної та колоїдної хімії для подальшого успішного опанування спеціальними дисциплінами, а також сприяє виявленню міжпредметних зв'язків, що, у свою чергу, підвищує мотивацію до навчання.

2. Діаграми плавкості, кипіння та розчинності мають важливе значення для фармацевтичної науки i технології. Тому одним із головних завдань викладача $є$ формування у студентів умінь та навичок побудови й аналізу подібних діаграм.

цевтичному університеті / [В. П. Черних, В. М. Толочко, Л. Г. Кайдалова та ін.]. - Х. : Вид-во НфаУ, 2004. - 68 с. 
2. Освітні інновації в Національному фармацевтичному університеті / В. П. Черних, Л. Г. Кайдалова, В. М. Толочко, Т. Ю. Вахрушева. - Х. : Вид-во НФаУ, 2005. - 248 с.

3. Програма з фізичної та колоїдної хімії для студентів вищих фармацевтичних закладів освіти та фармацевтичних факультетів вищих медичних закладів освіти III-IV рівнів акредитації/ [В. І. Кабачний, Л. Д. Грицан, Л. К. Осіпенко та ін.]. - К., 1998. -24 c.

4. Програма з фізичної та колоїдної хімії для студентів спеціальності 7.110204 “Технологія фармацевтичних препаратів” вищих закладів освіти III-IV рівнів акредитації / В. І. Кабачний, Л. Д. Грицан, Л. К. Осіпенко, В. П. Колєснік. - К., 2000.-28c.

5. Програма з фізичної та колоїдної хімії для студентів вищого фармацевтичного навчального закладу та фармацевтичних факультетів вищих медичних навчальних закладів III-IV рівнів акредитації. Напрям: “Фармація”. Спеціальність: "Технологія парфумерно-косметичних засобів" / В. І. Кабачний, Т. О. Томаровська, Л. Д. Грицан, Л. К. Осіпенко. -К., 2011.-64 с.

6. Курнаков Н. С. Введение в физико-химический анализ / Н. С. Курнаков. - М.-Л. : Изд-во АН СССР, 1940. -564 с.

7. Курс физической химии : в 2 т. / [Я. И. Герасимов, В. П. Древинг, Е. Н. Ерёмин и др.]. - М. : Химия, 1969. T. $1 .-592 \mathrm{c}$.

8. Фиалков Ю. Я. Двойные жидкие системы / Ю. Я. Фиалков. -К. : Техніка, 1969. -220 с.

9. Ландау Л. Д. Статистическая физика. Часть $1 /$ Л. Д. Ландау, Е. М. Лифшиц. - М. : Наука, 1976. -584 с.

10. Красовский И. В. Физическая и коллоидная химия / И. В. Красовский, Е. И. Вайль, В. Д. Безуглый. - К. : Вища школа, 1983. - 352 с.

11. Новосёлова А. В. Фазовые диаграммы, их построение и методы анализа / А. В. Новосёлова. - М. : Изд-во Моск. ун-та, 1987. - 152 с.
12. Валяшко В. М. Фазовые равновесия и свойства гидротермальных систем / В. М. Валяшко. - М. : Наука, 1990.$270 \mathrm{c}$.

13. Евстратова К. И. Физическая и коллоидная химия / К. И. Евстратова, Н. А. Купина, Е. Е. Малахова.-М. : Высш. шк., 1990.-487 с.

14. Грицан Л. Д. Термодинамика фазовых равновесий / Л. Д. Грицан, В. И. Кабачный. - Харьков : Изд-во УкрФА, 1995. $-68 \mathrm{c}$.

15. Фізична і колоїдна хімія / [В. І. Кабачний, Л. К. Осіпенко, Л. Д. Грицан та ін.]. - Харків : Прапор, Вид-во НФаУ, 1999. $-368 \mathrm{c}$.

16. Біофізична та колоїдна хімія / [А. С. Мороз, Л. П. Яворська, Д. Д. Луцевич та ін.]. - Вінниця : Нова книга, 2007. -600 с.

17. Физическая и коллоидная химия / [В. И. Кабачный, Л. К. Осипенко, Л. Д. Грицан и др.]. - Харьков : Изд-во НФаУ, 2010. - 432 c.

18. Лебідь В. І. Фізико-хімічний аналіз / В. І. Лебідь, Л. Д. Грицан // В кн. : Фармацевтична енциклопедія. -2-е видання. -К. : Моріон, 2010. - С. 1481-1482.

19. Лекції з фізичної хімії / В. І. Кабачний, Л. Д. Грицан, Т. О. Томаровська, Л. К. Осіпенко. - Харків : Вид-во НФаУ: Золоті сторінки, 2012.-280 с.

20. Державна Фармакопея України / Держ. п-во “Науковоекспертний фармакопейний центр”. - Харків : РІРЕГ, 2001.-556 c.

21. Безуглий П. О. Фармацевтичний аналіз / [П. О. Безуглий, В. О. Грудько, С. Г. Леонова та ін.]. - Харків : Вид-во НФаУ; Золоті сторінки, 2001.-240 с.

22. Муравьёв И. А. Несовместимость лекарственных веществ / И. А. Муравьёв, В. Д. Кузьмин, А. Н. Кудрин. М. : Медицина, 1978. -250 с.

23. Фізична та колоїдна хімія. Збірник задач / [В. І. Кабачний, Л. К. Осіпенко, Л. Д. Грицан та ін.]. - Х. : Вид-во НФаУ; Вид-во ТОВ “Золоті сторінки”, 2001.-208 с.

Отримано 26.01.15 